\title{
Politicized Challenges, Depoliticized Responses: Political Monitoring in China's Transitions
}

\author{
Fu Hualing
}

\section{INTRODUCTION}

Having experienced a painful process of transition from revolution to modernization over the past 60 years, China now faces the mounting social, economic and political challenges that regularly face transition states. While the Chinese Communist Party-state proves to be resilient and able to adapt, innovate and evolve, it is also well-known that the social and economic transitions in China have produced significant strains on the political system. How does the Chinese state differ from the liberal democracies discussed in this volume in managing social and political risks?

This chapter examines the evolving strategies of political control in China. Following this introduction, Part 2 points out the increasingly politicized challenges that the Chinese Communist Party (the Party) faces and also offers an explanation for the reasons behind the politicization or the mainstreaming of politically motivated challenges. Part 3 introduces the paradigmatic shift in the Party's control strategy from open political repression to an apolitical, less ideological social management in regulating the increasingly politicized challenges. Parts 4 and 5 of the chapter identify and critically examine the new strategy. While Part 4 explains an emerging depoliticization process in 
which China's efficiency-based control strategy develops, Part 5 takes a closer look at that strategy and the formation of a new control culture. Part 6 is the conclusion.

\section{THE POLITICIZED CHALLENGES}

Political dissidence aiming at regime change in China has gained momentum despite the harsh repression. ${ }^{1}$ Generations of political dissidents have campaigned for the end of the one party rule in China through peaceful means and have met harsh state responses, with most of them imprisoned or forced into exile. Yet, state repression and brutality have not deterred new generations of activists who continue to advocate for political changes. The sentencing of Liu Xiaobo to 11 years of imprisonment for organizing a Chartist movement did not quell the domestic calls for fundamental political changes. Instead, Liu's prosecution has provided a stimulus for a more sustainable political resistance. ${ }^{2}$

It is significant that the form that political dissidence may take has also evolved. Direct advocacy of regime change, in its traditional form, may have waned partly due to state

\footnotetext{
$1 \quad$ Ethnic tension has intensified in Tibet and Xinjiang and the separatist tendency is taking a stronger hold and entrenching T Shakya, 'Self-immolation: the changing language of protest in Tibet' (2012) 25 Revue d'Etudes Tibétaines 19; J V Hastins, 'Charting the course of Uyghur unrest' (2011) 208 China Quarterly 893. For a review of those challenges, see Fu H, 'Responses to terrorism in China', in Victor V Ramraj, M Hor, K Roach and G Williams (eds), Global Anti-Terrorism Law and Policy (Cambridge: Cambridge University Press, $2^{\text {nd }}$ ed, 2012).

2 J Beja, Fu H and E Pils (eds), Liu Xiaobo, Charter 08 and the Challenges of Political Reform in China (Hong Kong: Hong Kong University Press, 2012) 119.
} 
repression, as manifested in the aftermath of the so-called 'Jasmine Revolution' and the imprisonment of Liu Xiaobo in 2009; and partly due to the rising opportunity of rightsbased social and legal advocacy, as demonstrated by the popular weiquan (rights defending) movement. There is an increasing convergence between a right protection movement and the dissidence movement in that political dissent is increasingly embedded in and expressed through protecting social and economic rights. Dissidents have toned down their political rhetoric and are engaged in lower-risk ordinary social and economic issues, aiming at incremental political change through socio-legal advocacy. Dissidents are now concerned primarily with the rights of migrants, underground churchgoers; petitioners and the broadly-defined vulnerable groups.

Earlier generations of dissidents challenged the Party by setting up opposition parties but the new generation tries to mould and change the system through legal and constitutional reform. As Feng notes, dissent is now more embedded, rooted and become part of a larger rights movement, and both forces increasingly find themselves in a 'grand coalition of liberal forces' and use laws and mechanism associated with legal rights to tame, mould and change the political system. ${ }^{3}$ Dissidents are reaching out to and joining forces with the vibrant social forces, with a clear objective to use social justice and social and economic rights as an entry point for a political change.

\footnotetext{
3 Feng C, 'The threat of Charter 08', in Beja, Fu and Pils, ibid 119; Feng C, 'The rights defence movement, rights defence lawyers and prospects for constitutional democracy in China' (2009) 1 Cosmopolitan Civil Societies Journal 150.
} 
Routine protests for social and economic rights have become better organized and more forceful, and are developing some vaguely framed political objectives. Social and economic issues are drawing the attention, sympathy, support and participation of people from different walks of life and the accumulative force is presenting a unique challenge to the Party’s political stability and legitimacy.

There are quantitative and qualitative changes in protest. It is well-known that nowadays, protest happens more frequently, is much larger in scale when it happens, and has better organization and coordination. Large-scale protests are no longer limited to more remote areas such as Weng'an or Shishou. They are taking place in the coastal regions at the heart of China's export centres such as Jiangsu and Guangdong. Protesters represent a cross section of Chinese society and they protest against a diverse range of social and economic problems, such as labour conditions, environment degradation, poverty and corruption. Together they represent the broadly based bottom-up social mobilization with different degrees of legality, effectiveness and resilience.

Researchers have identified several qualitative changes in social protest in China and indicated a strong degree of politicization. Traditional social justice issues are increasingly framed in political terms and mass events in general have become much more politically informed and politically relevant. First of all, a collective identity is clearly emerging through the collective action. ${ }^{4}$ Armed with legal rights and a strongly

\footnotetext{
$4 \quad$ Leung $\mathrm{P} N$ and Pun N, 'The radicalization of the new Chinese working class: a case study of collective action in the gemstone industry’ (2009) 30 Third World Quarterly 551.
} 
felt moral entitlement, protesters are not only stepping out with confidence in making their claims, but also making the claims in an organized, common voice. The social and economic transition has rendered obsolete the old control mechanisms of fixed residential communities and static workplaces. Environmental protest has brought participants together from across the whole city; and workers from different factories coordinate their strikes and other industrial actions. Cross-profession and cross-community mobilization and protest have become possible. From isolated individuals who carried out 'spasmodic, spontaneous and uncoordinated' action for their legal rights, protesters have started to identify the commonality in their grievances beyond the specifics of their individual cases, and agree to a common course of action against common adversaries through coordinated action. ${ }^{5}$ The development of a common course and identity draws a larger number of people to the protest and creates a critical mass of protesters which in turn reduce the fear of participation and make the protest more sustainable. The growth in size and the development of common identity also necessitates better planning and coordination. As it happens, protesters have used information technology effectively in mobilization and have designed strategies to minimize and counter potential police suppression. ${ }^{6}$

Secondly, protest holds the government responsible either as the root cause of the problem or the adversary to a conflict. ${ }^{7}$ This is not surprising because major conflict occurs in land appropriations, labour protests and welfare claims in which the

$5 \quad$ M S Tanner, ‘China rethinks unrest’ (2004) 27(3) Washington Quarterly 137.

$6 \quad$ Tanner, ibid.

$7 \quad$ H Lu, 'State channelling of social grievances: theory and evidence in China' (2011) 41 Hong Kong Law Journal 547, 551. 
government is directly involved and held responsible. In land appropriation, the government benefits from land sales and often manipulates transactions from behind; in labour protests, the government restricts collective action, breaks up strikes and detains labour leaders; and in social welfare claims, the government is to blame for the failure to pay.

Thirdly, protesters are moving beyond their diverse individual grievances and have started to look into the political structure for remedies. The entanglement of government in social and economic issues and its vested interests aggravate social conflict and bring the political system directly into the conflict, hence the radicalization of protest. For example the anti-corruption protest in Wukan brought down a corrupt local government and resulted in the successful establishment of an autonomous governing body exercising political power independent of the Party; in the environmental protests in Chinese cities, residents went beyond the immediate issues and demanded the right to know, to express, to be heard and to participate; and on Guangdong's factory floors, workers have demanded not only higher pay and better working conditions, but also the right to vote for their own union members and the right to bargain as a collective body. Dissidence may be permeating into socio-economic issues and ordinary citizens are more politically informed and engaged. Many have observed a gradual convergence between the traditional regime change activities and the new generation of rights protection activities, with both aiming at political change through legal action and civil society mobilization. In the age of rights, political dissidents and rights advocates are no longer distinct. 
Finally, resistance is radicalizing and protesters have demonstrated their resolve not only to resort to non-institutional means in defiance of government prohibitions and police warnings, but also their readiness to escalate protest into violent confrontation. Violence is permeating the field of rights protection in China. At an individual level, there are 'individual terrorists', as they are referred to in certain policy circles, who committed hate crime with a degree of political motivation, with typical examples including the murders of police officers, judges, urban management personnel and other state representatives. ${ }^{8}$ While most of the rights protection activities are moderate and rights advocates are consciously upholding the non-violence principle, when rights are ignored for too long, desperate claimants may lose control and are forced to resort to force, or even extreme violence, to make their claims. ${ }^{9}$

At a collective level, vandalism and violence are increasingly becoming part of the rallies and demonstrations. In a recent environmental protest against the dumping of waste water by the Japanese paper mill in Qidong, Jiangsu province, angry residents ransacked the government offices and captured and humiliated the Party chief. ${ }^{10}$ Villagers of Wukan

\footnotetext{
$8 \quad$ Fu, above $\mathrm{n} 1$.
}

$9 \quad$ Pun $\mathrm{N}$ and Lu H, 'A culture of violence: the labor subcontracting system and collective action by construction workers in post-socialist China’ (2010) 64 China Journal 143; E Pils, 'Charter 08 and violent resistance: the dark side of the Chinese Weiquan movement’, in Beja, Fu and Pils, above n 2, 229.

10 Upon his refusal to wear a protest t-shirt, protesters took his clothes off by force and the topless picture of the Party chief was widely circulated. Lei D, 'The conflict without bloodshed between government and citizens implies the coming of drastic social transformation', Duli Zhongwen Bihui [Independent $\quad$ Chinese $\quad$ Pen $\quad$ Center $\quad$ (online), $4 \quad$ August 2012 
successfully drove away Party officials from the villages and violently confronted the police who attempted to enter the village through force. On many occasions, riots may be provoked by police repression and brutality, and demonstrators merely respond to unjustifiable force with violence. But on other occasions, demonstrators have become militant and make their statements through smashing shops, burning cars or otherwise vandalizing property. When a crowd gathers, a mob mentality soon develops and, with or without police provocation, a peaceful demonstration can easily turn into a riot, inviting further police brutality.

\section{DEPOLITICIZING CONTROL}

Facing the forceful and more politicized protest and resistance, within the context of successive colour revolutions ${ }^{11}$ that have toppled authoritarian regimes in different parts

of the world, the Party stepped up its control. ${ }^{12}$ It has concentrated control in the hands of the Party's political-legal system and given the political-legal committee the overall responsibility on stability maintenance with overriding authorities over legal institutions, effectively preventing the congress and courts from exercising any oversight functions

<http://www.chinesepen.org/Article/sxsy/201208/Article_20120804215057.shtml> (accessed February 2013).

11 The term 'colour revolution' is widely used to describe a variety of political movements which arose in several states of the former Soviet Union and the Balkans during the early $21^{\text {st }}$ century. The term has also been applied to a number of revolutions elsewhere, most notably in the Middle East.

12 T Chen, 'China's response to color revolutions: adaptive authoritarianism in full swing' (2010) 34 Asian Perspective 5; M E Sarotte, ‘China’s fear of contagion’ (2012) 37 International Security 156. 
over emergence issues. ${ }^{13}$ It has created empowering legislation to allow the state to monitor political expression and punish movement organizers. It has hugely increased the internal security budget and provided sufficient resources to meet the control demand. ${ }^{14}$ It has resorted to some ancien regime institutions to handle emergent situations; and it has attempted to resort to extra-legal violence to preempt the allegedly eminent risks. But the Party remains pragmatic and has adapted to the changing circumstances in political challenges. While firmly in control, it is willing to use alternative control strategies and the most significant change is the depoliticization of political control and the development of an apolitical and non-ideological control mechanism.

The most notable characteristic of political control in Communist China was class justice, which was to 'make an individual's class origin or political background a determining factor'. ${ }^{15}$ The dictatorship of the proletariat was the nature of state power; law was

13 For an overview of the stability maintenance structure, see $\mathrm{Xu} \mathrm{K}$ and $\mathrm{Li} \mathrm{W}$, 'The stability maintenance system', Cajjing Wang (online), 7 June 2011 <http:/www.caijing.com.cn/2011-0607/110738832.html> (accessed February 2013).

14 The budget for internal security in 2010 was RMB 514 billion, an 8.9 per cent increase from 2009.

The budget for national defense was RMB 518.6 billion for the same year. It has become a controversial issue how much China spends on domestic security or whether China spends more on internal security than national defense. But it is beyond doubt that China is spending a much larger budget on internal security than ever before: Lu, above n 7, 549.

15 Leng S and Hungdah C, Criminal Justice in Post-Mao China: Analysis and Documents (Albany: State University of New York, 1985) 19. 
designed to punish political enemies who allegedly opposed the regime. ${ }^{16}$ Traditionally, the Communist regime in China created its own enemies and its political control in the first thirty years of the Peoples' Republic relied on a clear distinction between the 'people' and their 'enemy'. The key feature of the class enemy was that once the status was ascribed and the enemy so labeled, it became inherent and permanent. ${ }^{17}$ The class enemy was totalistic in that the concept opposed the pure 'we' to the evil 'they', claiming that whoever was not with us was against us. Once attached, the label became a 'master status' and represented the 'total personality' of those who held it. When the dualism of enemy versus people applied, the system designed a dual mechanism to deal with enemy and people separately and differently. Harsh measures were applied to enemies and more moderate measures were applied to deal with conflicts among the people.

There was then the decisive change from revolution to modernization in the late 1970s. Facing political and economic stagnation and social chaos in the aftermath of revolutionary radicalism, the Party decided to shift from class warfare to economic reform. By 1979, most of the class enemies had their names cleared, and in 1981 the Party claimed the successful accomplishment of the historical task of reforming the class enemy. The ideal of equality of all citizens before the law was institutionalized in the 1982 Constitution, and class struggle and discrimination was finally ended.

$16 \quad$ M Meisner, 'The concept of the dictatorship of the proletariat in Chinese Marxist thought', in V Nee and D Mozingo (eds), State and Society in Contemporary China (Ithaca: Cornell University Press, 1983).

17 J Billeter, 'The system of “class status”, in S R Schram (ed), The Scope of State Power in China (Hong Kong: Chinese University of Hong Kong Press, 1985). 
In response to the larger political change, China has embarked on a course of depoliticizing control through a three-stage process. First, the concept of crime has been depoliticized and is seen principally through a legal lens as a violation of law. Crime was traditionally given a highly political definition, not so much as a violation of law but as a challenge to the political system. Depoliticized crime was alien to a socialist state because the causes of crime no longer existed in a socialist state. In this circular reasoning, the 'people' would not commit crimes against the state and so those who committed crime against the state must be the enemy of the people. Crime was used more as a tool for political repression than a legal instrument for social regulation, and as such it was poorly and broadly defined, if at all. The enactment of the 1979 Criminal Law was a milestone in bringing the law back to defining and punishing crime. Even the legalization of counterrevolution offence in the 1979 Criminal Law, a highly politicized law, was hailed, rightly so, as progress from the wanton political persecution in the previous decades, and was the first step toward bringing some legal certainty and regularity in this sensitive area. ${ }^{18}$

18 Counterrevolution was defined as an act 'endangering the People's Republic of China committed with the purpose of overthrowing the political power of the dictatorship of the proletariat and the socialist system'. Counterrevolutionary offences included three broad categories of crime. The first category was offences against state security including treason, espionage, subversion and other traditional crimes against the state. The second category related to three broadly based 'thought crimes' including the crime of organizing counterrevolutionary groups; using feudal superstition to carry out counterrevolutionary purpose; and counterrevolutionary propaganda. And the third category included ordinary criminal offences committed with a political purpose such as sabotaging with a political purpose motivation. The element of 
Secondly, the depoliticization of crime took place in the context of enhanced political tolerance. The Party in the reform era was characterized by consultative authoritarianism and pluralistic authoritarianism, and was more tolerant of different and critical voices. The promulgation of the 1979 Criminal Law witnessed a sharp decline of political offences in both the actual number and in its percentage in the overall criminal offences. There are many reasons that explain the decline, including a less political population and the creation of channels, such as litigation, effectively to divert and absorb political challenges. But a significant reason is that the Party had shifted its priority to economic growth and become more tolerant of political dissent. Correspondingly, legal institutions were forced to respond to the social changes. For example, the police were forced to tone down political rhetoric on the class enemy and class struggle and to make its priority the policing of surging street crime, to serve the economy. In turn, the courts had to divert resources to deal with the increase in civil and economic disputes.

Finally, the depoliticization of crime was followed by an equally important reform to depoliticize criminal law. The abolition of counterrevolutionary offences in criminal law reflected a political reality that the distinction between the people and their enemy could not be maintained. In the age of social and economic transformation, the 'enemies', having toned down their rhetoric and taken off their uniforms, are diversifying their counterrevolutionary purpose was not defined and in practice was objectively imputed. See, Fu H, 'Counterrevolutionaries, subversives, and terrorists: China’s evolving national security law', in Fu H, C Peterson and S Young (eds), National Security and Fundamental Freedoms: Hong Kong’s Article 23 under Scrutiny (Hong Kong University Press, 2005). 
challenges into a variety of social and economic issues. Once politics is taken away from the equation in defining crime, the requirement of rule of law, with its inherent characteristics, kicks in and becomes an integral part, formally at least, in the Chinese criminal law. The 1997 amendment of the 1979 Criminal Law reflected the social and political change and significantly changed the structure of counterrevolutionary offenses in the old criminal law. ${ }^{19}$

This depoliticization facilitated and even enhanced the level of control, however. For the law reformers, the abolition of the offences of counterrevolution was a significant landmark in developing the rule of law in China, symbolizing a shift of the country from a revolutionary state to a normal state following international examples. ${ }^{20}$ By taking political offences and political considerations behind criminal cases out of the equation in determining liability, a neutral analysis of the criminal law and punishment becomes possible. But for the state, depoliticization allows a high degree of legitimacy in political control and flexibility in punishing politically harmful activities through regular criminal law. Depoliticization allows the Party to move beyond the traditional model of repression that was designed for the class enemies and to use multiple regulatory tools in punishing and preempting political challenges. Repression may define authoritarianism, but it has proved to be ineffective in maintaining political control and regulating society in the changing circumstances.

19 The amendment largely abolished thought crime as it was persecuted before the amendment and also punished crime without constructing an unnecessary political motivation: Fu, ibid.

20 M Lobban, 'From seditious libel to unlawful assembly: Peterloo and changing face of political face of political crime c 1770-1820’ (1990) 10 Oxford Journal of Legal Studies 307. 
Depoliticization also witnessed a corresponding increase of judicial autonomy in criminal justice. In contrast to the law on political offences, there is better definition for ordinary crime and more regularity in criminal procedure. The enhanced quality of law, coupled with less political sensitivity, makes judicial legal analysis and reasoning a real possibility. Since law matters more in the court, criminal defense becomes more relevance and important. $^{21}$

Political trials remain. In subversion trials, for instance, incitement-based charges often resemble the old counterrevolutionary offences and punish mere thoughts and speech. The ghost of the class enemy haunts political trials, and once a dissident label becomes attached, the stigma stays and one's activity is interpreted through that political lens. When that happens, the question 'who he is' often becomes the decisive element of a crime, and as happened in Liu Xiaobo’s trial, criminal law goes beyond the mens rea and actus reus in allocating liability, to include the total circumstances of the case including the accused's record and motivation. ${ }^{22}$

However, political trials, while continuing to exist, have become less relevant in the overall control strategies. They are not only reduced in number but also diminished in their political significance. The archetype of political show trials took place in a public

21 Fu H, 'Institutionalizing criminal process in China', in Guanghua Y (ed), The Development of the Chinese Legal System: Change and Challenge (New York: Routledge, 2012).

$22 \quad$ Fu, above n 18. 
forum in which a large audience was invited to witness and experience the majesty of the state power and participate in the ritualistic process. The 'public trial' was used to demonstrate that the state was mighty but also right, and the moral submission of the enemy to the authority of the state was a necessity. Therefore, confession from the enemy, chanting of slogans, and parading of offenders through the streets were integral parts of the legal process. In that Durkheimian process, the Party crystallized the boundary between the people and their enemy and strengthened the solidarity among the people. The class struggle generated solidarity among the people in which the righteous people identified themselves as the moral majority against the morally inferior enemy. In the process, the enemy was used as a measure against which the boundary between virtual and evil, normal and abnormal and people and enemy was defined and re-defined.

Contemporary dissident trials no longer have the same education function and expressive value. As mentioned above, the number of political trials has significantly reduced and when they take place, they are conducted in great secrecy, hidden from any public purview. The invisibility is in part the result of the growing legal professionalism and institutionalization. For example, the Supreme People’s Court has effectively banned any form of parading of offenders during or after trials. But the decision to keep the public out in political trials goes beyond the concern of an enhanced professionalism and civility. The Party is aware of the possibility that a political trial is likely to reduce rather than enhance its credibility and the trial of dissidents, if not managed well, may become a trial of the regime itself. The defendants were no longer the class enemies who were overwhelmed by a powerful and righteous state. The current dissidents represent and 
speak for a larger social force composed of real people with diverse interest, and behind every dissident on trial there is a support group who is willing to stand up and continue with the resistance. The prosecution is an intervention into an on-going process of social resistance, which is unlikely to stop merely because of a prosecution. On the contrary, the prosecution may serve as a catalyst for further mobilization.

As a result, the Party has developed alternative strategies to punish dissidents without incurring unnecessary cost. The Party has taken a minimalist approach in political prosecution - to prosecute as little as possible in the circumstance and not to create an opportunity for courtroom confrontation unless absolutely necessary. Therefore the tightened political control does not show up in judicial statistics which have showed diminishing political prosecutions. Even when prosecution becomes necessary, the Party uses alternative charges to avoid political sensitivity in deterring and punishing activists or dissidents. It shatters non-governmental organisations for fire-code violations or applies pressure on landlords to end their rental agreements. It prosecuted Xu Zhiyong, Ai Weiwei and many others for tax evasion for their aggressive advocacy of public interest matters and harsh criticisms of Party policies.

Given the pragmatic objective of achieving control with minimum cost, high rhetoric has become marginal. Ritualistic trials, while continuing to exist to serve an incapacitation purpose, are no longer central to stability maintenance. Law has gradually lost its expressive utility and educational value. China is no longer a purely ideological state and what is important is to control the risk and compromise challenges in a quiet and 
effective way. From an efficiency perspective, political trial is a waste of resources and attracts unnecessary attention when other more cost-effective tools are available.

\section{ADMINISTRATIVE ABSORPTION OF POLITICAL CHALLENGES}

With the depolicitization and a non-ideological approach, the Party designs a comprehensive political-administrative strategy to absorb and capture the political challenges under various political labels such as harmonious society, stability maintenance or social management. Subsequent punishment through political trials has been replaced by surveillance and preventative and proactive intervention by security agencies; deterrence and suppression has been replaced by a strategy of control through social management and containment. Well-resourced security agencies respond to potential threats aggressively before they mature. ${ }^{23}$

The control mechanism is administrative in nature and largely bypasses the formal legal process. As practiced in China, these mechanisms are less visible, informal and operate on a case-by-case basis with an objective to preempt risk factors that may disturb stability and prevent the ferment of any collective action. In essence, the newly depoliticized control entails three interrelated approaches: enhanced and reinforced technological surveillance; preemptive intervention and de-aggregation of collective action; and the

\footnotetext{
${ }^{23}$ For a review of the operations of security agencies in other states see the chapter by Nicola McGarrity and George Williams in this volume..
} 
resort to harsh extra-legal measures. In Levitsky and Way’s terms, China has designed a system of low-intensity coercion to maintain political stability. ${ }^{24}$

\subsection{Surveillance Society}

The most visible sign of a changing strategy is the enhanced external control. The Party has resorted to technology to enhance its monitoring capacity in both the virtual and real worlds. In a society characterized by increasing individualization, high levels of mobility and enhanced levels of social and economic freedom, relying on external control becomes essential. Indeed, Chinese cities are now among the most watched in the world, and virtually every Chinese city is abundantly covered by CCTV. ${ }^{25}$ Take Guangdong province for example, which has about a million CCTV cameras and is planning to spend nearly US\$2 billion to install another million in the near future. ${ }^{26}$ Guangdong and Chongqing are by no means unique: Chinese cities are well-funded and pushing to enhance their surveillance capacity by installing further hi-tech CCTV. The quality of

24 S Levitsky and L A Way, 'The rise of competitive authoritarianism' (2002) 13 Journal of Democracy 51; S Levitsky and L A Way, ‘International linkage and democratization’ (2005) 16 Journal of Democracy 20; L A Way, 'The real causes of the color revolutions' (2008) 19 Journal of Democracy 55; L A Way, ‘A reply to my critics’ (2009) 20 Journal of Democracy 90.

25 B Bakken, 'The Chinese surveillance state: the rationalities of “social management” in China' (paper presented at the Conference on Stability and Law, Australian National University, Canberra, 8-9 November 2012).

26 F Tam, '2M spy cameras in Guangdong by 2015', South China Morning Post (Hong Kong), 15 June 2012. 
mass surveillance is also improving and digital cameras now have enhanced capacity in recognizing faces and vehicles and identifying suspicious gatherings, although the quality of surveillance in China may lag far behind that in London. ${ }^{27}$ Few accountability mechanisms are in place to put surveillance under effective legal control. While the public are aware of the potential for intrusion into their privacy and have debated the possible misuse and abuses of surveillance, they are mainly concerned by surveillance of their private domains and are highly supportive of surveillance in public places. ${ }^{28}$

The virtual world is put under even tighter control, and China is well-known for its censorship and blockage on the internet. King et al have characterized Chinese censorship as 'a stunning organizational accomplishment, requiring large scale militarylike precisions'. ${ }^{29}$ While researchers have documented the level and scope of censorship in great detail, focusing on the system's capacity to block overseas websites, filter sensitive words and deleting sensitive comments, ${ }^{30}$ there is less understanding on how the system monitors, tracks and controls. The hi-tech monitoring of activists - interception of communications, hacking into websites and emails and tracking suspects, all statesponsored - are less well known as censorship. Human rights lawyers and other activists

$27 \quad$ See the chapter by Jens Kremer in this volume.

28 Bakken, above n 25. The chapters in this volume by Merris Amos and Conor Gearty point to a similar level of tolerance of resistance towards surveillance in western democracies.

29 G King, J Pan and M Roberts, 'How censorship in China allows government criticism but silences collective expression’ (2013) 107 American Political Science Review 10 (forthcoming).

$30 \quad$ King, Pan and Roberts, ibid. 
are very familiar with the police capacity to intercept and monitor their communications and often take extra caution in using information technology to avoid surveillance.

This enhanced external control, based on technology, should be understood in the larger context that traditional control mechanisms have been in decline during China's social and economic transition. It is well documented that the pillar of the traditional social and political control based on residential committees and work units are largely collapsing due to the individualizing forces of a market economy and economic growth. Other state control mechanisms, such as the control over workers' unions and social organizations, are under stress and can no longer cope with the bottom-up claims for interests and demand for rights. ${ }^{31}$ While control remains resilient, challenges are taking deeper roots and inching in steadily. In additional, new social forces, such as the legal profession and social media, are emerging to test the political bottom-line of the Party. The success of enhanced technological control is also a sign of the diminishing capacity of the Party to grip the changing society.

That failure is most clearly seen in the enhanced political monitoring and intervention at the individual level. Beyond general monitoring in the real and virtual worlds, China has had a tradition of sophisticated control that specifically targets certain individuals and groups, which forms the crux of the Party's political control. With vanishing prosecutions, the security apparatus has stepped forward to preempt threats directly. China is following

$31 \quad$ F Wu and K Chan, 'Graduated control and beyond: the evolving government-NGO relations' (2012) 3 China Perspective 9. 
the larger international trend to rely on the security apparatuses to take preemptive measures including infiltration into activist society groups, monitoring and harassing activists, and compromising any risk factors before they materialize. They now operate in the open and display their power in public, playing a much more proactive role in political policing. They are powerful, intrusive, and occasionally thuggish. They reach out not only to civil society organizations, professional groups and business communities, but also to other government departments, influencing the decisions of tax authorities, business administration, academic institutions, banks, hotels, and landlords.

The politicization of social protest based on social and economic issues has made the traditional strategy of political control impossible. The Party is facing new challenges as mentioned above. The sources of challenges are multiple; the issues involved are wideranging, and the aggrieved people come from different walks of life. Once the control net is cast so as to cover a wide range of social and economic issues and rule of law concerns, a large number of individuals come onto the horizons of the security apparatus. This is a significant departure from the past practice when the target of political control was limited to a small group of well-categorized people. Now people with potential risks are expanded to include lawyers, reporters, civil society activists, academics, Chinese staff working in foreign organizations, etc - the list is potentially unending. The net is cast wide but the targets and objectives are clear: the priority of political monitoring is placed on individuals, organizations and social forces that have the potential to mobilize communities and organize protests. ${ }^{32}$

32 Tanner, above n 5. 
The broadening of political control, the frequent encounters with the security apparatus on regular social and economic issues, and the inclusion of some of the social elites in the control net, all contribute to the reduction of fear among those at the receiving end. It desensitizes the issue and reduces the authority of the security apparatus. Traditionally, an interview with the security organ was regarded as a serious political matter and a threat of it would strike sufficient fear as to secure compliance. Once the veil of secrecy is pierced through, the level of fear diminishes substantially.

\subsection{Preemption and Disaggregation}

Facing the diversified and persistent challenges that are politicizing, the Party has designed multiple preemptive mechanisms to prevent any aggregate effect. A key strategy of general intervention is the promotion of aggressive mediation and the imposition of a duty on all government departments to end disputes proactively as quickly as they occur. Courts in particular are encouraged to mobilize available resources to bring conflicts to an effective end at any cost. The interventionist and proactive style of dispute resolution aims at preventing conflicts from foaming, escalating and solidifying, regardless of their political orientations.

Reflecting the larger trend of depoliticization, the Party is no longer defending any ideological claims or proving the legitimacy of certain political doctrines. It is taking a pragmatic approach in identifying and classifying potential threats assorted by levels of 
dangerousness, taking preemptive measures and removing any risk factors. The Party is no longer interested in mere ideological differences and the focus has decisively shifted to the likely social impact of certain courses of action rather than the ideological background that may motivate and inform the action.

The Party now tolerates challenging political rhetoric including even some extreme, but harmless, language used against the Party. It is not punishing speech per se but carefully assessing its impact. As King, Pan and Roberts have shown, mere online criticisms, as 'vitriolic' as they are, are not the primary target of Chinese censorship. It is postings that are likely to spur collective action that attract the wrath of China's censors. ${ }^{33}$

Indeed, even statements that are in support of the regime get censored. The test is not the political correctness of the speech but the possibility to ignite a collective action. In that sense, the suppression is 'politically neutral': the security apparatus pays little attention to the political views of its targets and is reluctant to engage in discussion on value questions including questions relating to the legality of certain policies or the legitimacy of the Party. The concern is merely pragmatic. One's ideological orientation and the long term value of activities are of little concern now, and the only issue is whether the course of action, if left unchecked, would produce some significant unstable factors. The regime is willfully colour-blind.

33 King, Pan and Roberts, above n 29, 5. 
One's political stance, that is, whether one supports the Party, is no longer the dividing line in political monitoring and what really matters is whether what one does generates a risk factor that may adversely affect stability. Thus, religious cults are grouped and controlled in the same way as petitioners fighting for social justice and economic rights; separatists receive a similar treatment as land owners fighting for their land rights and activists in environmental and labour protests.

Unstable factors, political or otherwise, are now commonly referred to as 'sensitive cases', an umbrella concept which includes an indefinite range of cases and events. A case becomes politically sensitive if it relates to the conventional national security issues, including high profile political dissidents, underground religions and anything concerning a potential colour revolution. But increasingly, sensitive cases refer to the so-called 'mass cases', cases that relate to the daily life activities, such as unpaid wages or unsafe food, but happen to involve multiple participants in a conflict. Sensitive cases thus touch on every policy areas. Risk factors have spread and the enemies are among us.

The focus of the control is often on the prevention and control of collective conflict, or mass event, defined as a dispute involving a certain number of people. Collective dispute, as mentioned above, often relates to a government department and is prone to collective action and street protest, as such, is given high political attention and treated with great care. 
Even when individual grievances are coalescing into a broader and sustained protest, the Party still tolerates the disturbance and refrains itself from violent clamping down while trying to defuse the issues and prevent further escalation. In general, it is commonly observed that the Party has become more tolerant of (potentially politicized) protest and accommodative of protesters' demands. Indeed, some commentators have argued that the Party relies on protest to solve its agency problem and it is not the suppression of protest but the tolerance of it that has contributed to the Party's stability. The government is accommodative and the police are strictly prohibited from using weapons or police devices in policing protests. ${ }^{34} \mathrm{By}$ and large, the government has been able to bring protests to a speedy end and avoid the backfiring that is associated with repression. The system now responds rapidly and is willing to compromise, even though the accommodative policies may have been seen as an incentive for more protests.

\subsection{Extreme Measures}

Reliance on preemptive measures does not necessarily mean the authoritarianism has become kinder or gentler. The containment strategy does not necessarily reduce the level of repression; it equalizes it in the sense that, through the preemptive strategy, violence is spreading from the dark corner of an interrogation room to the larger society. As mentioned above, security agents are now visiting a wide range of individuals and organizations in the society, sending direct or indirect warnings to those who receive a

$34 \quad$ Y Su and X He, 'Street as courtroom: state accommodation of labor protest in South China' (2010) 44 Law and Society Review 157. 
visit, an interview or an invite-to-tea that what they do may be problematic and they are being monitored. Violence is taking place at restaurants, teahouses, non-governmental organisations, law firms and academic institutions.

When the low-level coercion fails to work, as is often the case, the Party returns to extreme measures. Rule by terror wanes but does not disappear. At times of normalcy, China is developing law and making an incremental transition from rule-based governance. Over the decades, the Party has become more tolerant of protest and sympathetic to the protesters' grievances. It has also blamed local officials for causing and mishandling protests. But limited self-constraints do not mean the Party is no longer repressive when it considers that repression is called for. Authoritarian at its core, the Party is willing to reflex its authoritarian muscles when facing a crisis, perceived or real, and is decisive in abandoning legal rules and operating outside the legal framework. Eventually, when a real emergency is perceived, the Party draws a line in the sand to separate the enemy from the people even though the line is arbitrary and endogenous. Depoliticized control is prone to degenerate into one without any moral principle, and amoral control sees no bottom lines in designing control strategies.

Yet, in the depoliticized context, extreme political control exhibits its own characteristics - what I would refer to as the mobilization of extra-extra law. ${ }^{35}$ Extra-extra law

35 Law is defined here as a constitutional legal regime in which properly constituted authorities make and state legal norms (in a legal format) which are subsequently applied fairly by independent tribunals. There is a credible process of legal representation and judicial deliberation and a degree of transparency, and external accountability throughout the decision-making process. Extra-law is defined as an official 
comprises government measures that exist in some dark space, seemingly unrelated to any legal framework and devoid of any legal authority. It is an informal political institution characterized by a total lack of legality. It is used to advance some predatory and repressive government policies which cannot be justified by any law or extra-law. As such, extra-extra law is covered in secrecy and operates with no legal accountability. Except occasional and indirect admissions, such as the quasi-official admission of the existence of 'black jails' for petitioners, it does not officially exist, and, as such, it survives and thrives because it is effective in achieving certain policy goals which cannot otherwise be achieved through law or extra-law. The legal or even the extra-legal system is regarded as weak and ineffective when it comes to sensitive issues. In these situations, intimidation through extra-extra law becomes expedient and even indispensible.

There is a fundamental difference between enforced disappearance (extra-extra law) and abuse of criminal procedure (law). When the government uses, or even abuses the law, it still signals a commitment to law and a degree of fidelity to legal rules. There is also a degree of legal accountability and responsibility. That explains why human rights lawyers and others who were kidnapped may have demanded their day in court - so that abuses could be brought to the attention of the law and public scrutiny. The mere trappings of legality may not be sufficient to convert a political persecution into a fair legal process, but it is a necessary first step in developing the rule of law.

system in which power is neither directly derived from properly constituted authorities nor subject to independent oversight (judicial or otherwise). It has a strong political or policy orientation and the whole system is largely geared to political expediency or convenience: Fu H, 'Varieties of law in China' (2011) 12 China Rights Forum <http://www.hrichina.org/crf/article/5422> (accessed February 2013). 
What distinguishes the most recent repressive episode from the previous ones may be the potential to institutionalize extra-extra law and a strong sense of entitlement and confidence in using those extraordinary measures. China is gaining impressive economic power under the Party's leadership and the Party has become more confident in its legitimacy and ability to rule in its own way. At the same time, the Party is facing unprecedented social, economic and, to a lesser degree, political challenges. It feels its vulnerability strongly. But law is not currently perceived to be the most effective tool to handle the emerging crisis.

\section{CONCLUSION}

The Chinese Party-state faces diversified political challenges, including the boundary change and regime change challenges and those posed by growing social and economic issues. A defining characteristic of those resilient and well-organized challenges is their express political agenda. Ultimately, the Chinese political system, that is, the monopoly of power by the Party, is perceived as the root cause of all social ills, and the reform of that system or an outright regime change is often taken as a necessary pre-condition of or even the first step to meaningful reform. This is a legitimacy crisis that a democracy does not face and presents a unique set of difficulties for the Party.

In response, the Party has depoliticized crime, criminal law and political control strategies by declaring the end of class struggle and abandoning the rhetoric of 
counterrevolutionary crime. It has also minimized the use of political trials and resorted to the ordinary criminal law to punish politically-motivated challenges. At the same time, the Party has enhanced its capacity for external monitoring and surveillance and has invested in social management so as to preempt, capture and divert the growing social and political tension.

The difference between democracies and authoritarian states may not mainly lie with the threats that both face but their reactions to them. In a globalized world, risk is globalized and all states face grave challenges to their respective political structures. However, democracy reacts to crisis with significant difference and manages risks largely within the existing legal framework and according to democratic principles. The Chinese state reacts very differently. Like other transition states, China is slowly responding to social and economic challenges by improving governance, developing the rule of law and opening up certain political spaces. There are forceful demands for, and to a lesser degree political commitment to, transparency, legality and accountability. But while China may have been developing towards a rule-based legal system, in times of extraordinary threats, real or perceived, the limited rule of law and legal constraint on political powers vanish quickly. Law and legal institutions do not have the powers and capacity to manage and regulate the politicized challenges. When preemption and regulation fail, repression becomes the default position. When the Party faced the crisis brought out by the 1989 democratic movement, the Falun Gong, the China Democracy Party, the Tibet unrest, the Xinjiang riots, Charter 08 and the Jasmine revolution, the authoritarian nature of the 
regime, uncontrolled by and unaccountable to law, was laid bare. ${ }^{36}$ Repression of course does not offer a long-term solution, and the intense political monitoring and preemptive measures are also very costly and labour-intensive. But given the nature of the regime and the problems it is facing, the Party may have decided to govern on a crisis mode until it faces a much big crisis than it can handle.

$36 \quad$ J de Lisle, 'Security first? Patterns and lessons from China's use of law to address national security threats’ (2010) 4 Journal of National Security and Policy 397. 